\title{
Biophilic urban regeneration: can biophilics be a land value capture mechanism?
}

\author{
A. Cabanek \& P. Newman \\ Curtin University Sustainability Policy Institute, Australia
}

\begin{abstract}
There is strong evidence for environmental, economic and social benefits derived through the applied methodology of biophilic design. Early data on the impacts of biophilics provides evidence for the significant increase in urban land and property prices as well as the public value of ecosystem services. The need for urban regeneration has been proposed for cities to prevent the impact of urban sprawl to create more sustainable outcomes in energy, water and waste. To make urban regeneration happen requires an increase in urban amenities so that investment becomes worthwhile. This paper attempts to examine how biophilic elements of different scales can be used in urban regeneration and whether it can assist the regenerative city agenda. The land value capture mechanism has been proved successful in many North American cities. Through analysis of selected case studies, the paper demonstrates how the role of biophilics could be better implemented by governments and private investors as a core factor in creating urban regeneration projects.

Keywords: biophilia, biophilic design, urban regeneration, land value capture.
\end{abstract}

\section{Introduction}

The principles of biophilic cities have been outlined in a number of publications and are increasingly being demonstrated around the world [1]. The value of any urban nature interaction has been assessed positively but the mainstreaming process remains elusive. Urban planners and designers have become increasingly aware of the economic benefits that urban greenery can create [1-3]. This paper suggests a possible funding mechanism to enable biophilic urbanism to be mainstreamed as a part of urban regeneration. The concept of land value capture 
started in the United States as a way of funding urban regeneration at local government level $[4,5]$. Because urban regeneration through street furniture, landscaping and urban infrastructure increases the value of properties, there is a consequent increase in local taxation returns through rates, land taxes and sales taxes. These increases can be estimated and used as a hypothecated fund to pay for the financing of the improvements. The method has been adapted for funding urban rail in the United States, the United Kingdom and Australia [4]. This paper examines whether land value capture could be used to fund the mainstreaming of biophilic urbanism projects.

\section{Methodology}

Literature relating to biophilic design and the valuation of biophilic elements was sourced from bibliographic databases, university libraries and the internet. A number of case studies were selected to investigate the relationship between real estate value and green and blue infrastructure to prove the argument that biophilic elements of different scales enable urban regeneration to become attractive for private and public investments.

The analysis of selected case studies provides an insight into the benefits of thoughtful and strategic implementation of green infrastructure in commercial and private housing developments [6]. The methodology most commonly used to estimate the impact of green infrastructure on real estate value is called hedonic pricing. This methodology is often used in cases where non-market environmental goods and services such as air and water quality, and proximity to green spaces are considered value enhancers for adjacent land and properties. Often the valuation is based on comparing properties that differ with respect to their distance from environmental amenities such as parks, wetlands, recreational sites, open space or communal gardens [7].

\section{Biophilia}

The term 'biophilia' was first used by psychologist Erich Fromm to describe humans' natural affiliation and 'love for nature' [1]. In the 1980s it was adopted by world-renowned biologist, Edward O. Wilson, when he realized the negative consequences of ongoing separation of people from nature. Wilson described biophilia as "the affiliation of human beings to other living organisms" $[1,8]$. According to Kellert, biophilia is a missing link in sustainable design. Kellert [9] provides background theory for biophilic design, "a design approach in the built environment". Wilson and Kellert [10] stated that the main objective of biophilic design is to be "the deliberate attempt to translate an understanding of the inherent human affinity to affiliate with natural systems and processes ... into the design of the built environment" [11]. Biophilia, as a background methodology, considers the multidimensional and interdependent complexities of urban systems and infrastructure to provide restorative, regenerative spaces capable of mitigating the destructive effects of the urban heat island effect, storm water, air pollution, electricity demand and biodiversity loss [3]. 


\subsection{Biophilic urbanism}

Beatley [1] described it simply as biophilia on an urban scale. Biophilic urbanism is a relatively new term which also can be explained as "the principle of harnessing natural features as functional design elements, particularly in buildings" [12]. It has also been described as an approach in "bringing nature to our doorsteps" by intentionally designing the outdoors to reconnect people with flora and fauna [3]. The main role of biophilic urbanism is to create an environment that is "psychophysiologically and cognitively restorative" [13]. This is to reverse the trend of downgrading natural ecosystems from city spaces due to the increasing density of the built environment and instead enabling structures to become regenerative to natural ecosystems [14].

\subsection{Biophilic urban design}

Biophilic urban design aims to create healthy, attractive and interconnected urban environments such as green corridors, green belts, networks of urban 'living architecture' using vegetated walls and roofs [1], rivers and canals as potential sites for new habitats and biodiversity hotspots. Biophilic design promotes development of educational facilities, and the design of infrastructure in such a way that encourages interaction with nature, whilst engaging inquisitive minds of all ages in their natural environment.

To achieve meaningful and beneficial biophilic design, a number of principles have been proposed [9]: the experience of nature in the built environment should be repeated, ongoing and sustained; the design should consider human adaptation to the natural world that over thousands of years have advanced people's health and wellbeing; attachment to particular ecological and cultural settings and places should result from design; positive interaction between people and nature should be created; connected, mutually reinforcing and integrated architectural solutions should result from the design.

Biophilic cities are different from green cities. In biophilic cities the emphasis is put on wellbeing and health, celebrating living forms and processes. A green city's main objectives are to reduce energy consumption, minimize environmental impact, and enhance environmental conservation [1].

\subsection{How does landscape architectural design differ from biophilic design?}

Biophilic design is a methodology which could and should be used by landscape architects and designers to create healthy, meaningful spaces. Landscape architects tend to design spaces embodying a client's vision of the place. There is pressure to create visually appealing places, but not necessarily restorative ones, neglecting rather than enhancing biodiversity and ecosystem services. Some designs end up producing non-living landscapes. This could be avoided by applying the principles of biophilic design to every project. The methodology of biophilia aims to create urban landscapes to become living systems [13]. To design a living, restorative urban space, a landscape architect may consider using the fourteen patterns of biophilic design specified by Terrapin Bright Green [13]. The 
patterns observed in the natural environment can be used as the framework to apply biophilic design in the built environment. Each pattern aims to meet the health, social and economic priorities of the project owner at the same time providing solutions to the evolving needs of the ecosystems [15]. The fourteen design patterns are adaptable and replicable strategies for improving the usernature encounter that can be implemented under many circumstances [14].

\section{Land value and biophilic urbanism}

Some of the key environmental factors affecting property and land prices are greenery, surface water, noise impacts and landscape features. The main focus of this study is to establish how strongly biophilic elements impact the land and property value. The first part in this section examines the land value increase due to traditional green spaces. In the second part it will be shown how innovative biophilic structures, such as green walls, roofs and elevated parks, contribute to the increase of land and property values. The paper will then show how it is possible to capture this land value as a funding mechanism.

\subsection{Urban green and blue infrastructure and its impact on property value}

Crompton's [16] analysis of 30 case studies investigated the relationship between real estate value and proximity to parks; they confirmed the argument that urban green spaces contribute to higher property values. He estimated a 20 percent increase in the value of properties adjacent to park areas when assessing property value increases attributed to urban green spaces.

A study of 3000 properties in Philadelphia conducted by Wachter [17] showed the effect that investing in green infrastructure has on property value. The author focused on converting vacant land into quality green spaces. The results suggested that turning a vacant lot into a green space could potentially increase surrounding properties value by 30 percent.

One of the flagship examples of restorative projects, resulting in a regeneration of a significant urban area, is Cheonggyecheon Stream Restoration Project in Seoul, South Korea. In 2001, the Mayor of Seoul proposed removing Cheonggye freeway and restore the Cheonggyecheon River in order to revitalize the area economically and restore the status of 'pride of Seoul' for the area. According to a survey conducted, the project proposal was supported by 79 percent of residents. Completed in September 2005, the project became a source of tremendous pride for Seoul [18]. The main economic benefits from the project features a significant increase in the price of land by $30-50$ percent for properties within 50 meters of the project, which doubled the increases in other parts of Seoul. The cost of the project was $\$ 380$ million and the restoration has served as a catalyst for an estimated 22 trillion won ( $\$ 1.98$ billion) worth of capital investment in the Cheonggyecheon area redevelopment that would not have otherwise been invested. The case study is an example of successful urban regeneration where blue and green infrastructure become incentives for economic development [19]. 
Canalside regeneration project in Birmingham City Centre in the United Kingdom is another notable example. According to the study led by GHK in 2009, the net impact of the canalside development on property values was between $£ 25.7$ and $£ 57.1$ million [20]. In 2014, Birmingham became a member of Biophilic Cities Network. The city has committed to become green and sustainable and to enhance connections between health and nature. To achieve these objectives, the Green Living Spaces Plan was prepared by the city council. The most impressive project Birmingham has committed to is a creation of a network of rivers and streams which serve as a grid of trails and pathways for the citizens, as well as restoring their natural ecosystems.

The Birmingham canalside regeneration is an example of the impact of biophilic design on urban economic growth. The project has provided recreational and aesthetic ecosystem services as well as improving water quality in the rivers and canals.

\subsection{Green roofs, walls and elevated parks and their impact on land/property value}

In the report published by Smart Cities Research Centre [7], the properties with accessible green roofs are subject to 11 percent property value premium. Also, the analysis of the properties featuring rooftop food gardens demonstrated an increase of 7 percent in property value. The adjacent properties could gain between 2 and 7 percent, and those who have views onto a green roof could potentially gain up to 4.5 percent of property value.

Research about the impact of green walls on property value is emerging. Green walls, also called vertical gardens, are an easily identifiable symbol of the sustainable building movement since they are visible and increase green area ratio in urban centres [21]. A report prepared by Peck et al. [22] stated that in Toronto (Canada) property values increase 6-15 percent for buildings when they include green walls. Des Rosiers et al. [23] estimated that a green wall could add 3.9 percent to a property value. This figure was based on the analysis of property data in Quebec (Canada). Also, the Growing Green Guide points to a green wall as a factor that could add value to any property but is lacking concrete examples and figures. Further research is needed to estimate the value green walls could add to properties in other countries.

One of the most successful urban regeneration projects featuring many aspects of biophilic design is the High Line - an elevated urban park in Manhattan (the United States). It was built in three phases between 2006 and 2014 on a neglected freight rail lane. The project was developed and promoted as an economic regeneration of an industrial area and has become one of the major tourist attractions in New York $[1,24]$. The High Line project significantly lifted the value of surrounding properties, stimulated the commercial and residential property market resulting in an estimated $\$ 4$ billion in private investment [1].

The idea of saving the freight area from demolition came from residents, who founded a not-for-profit organisation, 'Friends of the High Line". Thanks to the successful marketing campaign launched by the organisation, the general public became well informed about its potential and the significance of the proposed 
regeneration project. Supporters of the High Line, including some members of the city council, obtained significant funds to develop the project. 'Friends of the High Line' managed to raise $\$ 300$ million from private investors to finance the completion of the project and the ongoing maintenance [24] on the basis that it would improve the value of their properties.

'Friends of the High Line' studied the potential economic gains for the freight line area. These studies projected how incremental tax revenues created by higher real estate values around the park would outweigh the costs.

Levere [25] assessed the High Line's impact on house prices by looking at property sales and figures. The amount calculated was an impressive $\$ 100$ million increase in property taxes that the city gained in 2010 alone. Compared with the overall cost of the project, the financial benefits generated by the High Line significantly outweighed the costs and the profits continue to raise revenue.

Factors that led to the successful execution of the project were, according to Ascher and Uffer [24]: the marketing campaign carried by 'The Friends of the High Line' and their celebrity supporters; political and federal support; the publicprivate partnership between 'Friends of the High Line' and the Government; the re-zoning and new regulations that allowed potential development to the area.

The High Line initiative shows an alternative way of funding green infrastructure projects, using projected tax revenues and other financial benefits to activate a project. In the case of High Line, its popularity led other cities to try and replicate its success. Similar elevated greenways and linear parks have been planned for Chicago, Philadelphia, Atlanta and Rotterdam [26], proving that private and public investors are starting to recognise the value of urban regeneration using biophilics.

A commercial building at 158 Cecil Street in Singapore is another successful example of how greenery can transform the uninspiring commercial interiors into an experience of nature, and at the same time provide significant financial benefits to the owners of the property. In 2007, Alfa Investment Partner acquired the property at 158 Cecil Street for $\$ 235.5$ million [27, 28]. The building failed to attract tenants due to its unattractive appearance and out of human scale proportions [29] so the new owner decided to improve the image of the building. The designers from Tierra Design + POD proposed living walls to be installed. The blank façades and columns were covered with ornamental plants creating 'a living cathedral' effect. 13,000 potted plants were installed covering 350sqm of surfaces as well as 7 sqm of hanging plants on balconies [29, 30].

Notable tenants in 158 Cecil Street included social media platform giants, Facebook, Bank of India, Zurich Insurance and also Airbnb [27, 29]. Due to the growing interest in lettable space, the owner was able to raise the rent of the office space. Apart from the increase in rental fees, the green walls provided a number of benefits such as improving air quality and regulating the temperature inside the building. The success of the refurbishment was confirmed by a number of design awards the project won, for example, First Price at Skyrise Greenery Award (2011), FuturArc Green Leadership Award (2012) and World Best Vertical Garden Design Gold Award (2012) [31]. 
In 2015, a company linked to an investor Denis Jen bought the property for S\$240 million from Alpha Investment Partners. Notably, several other parties were interested in acquiring the building [28]. In summary, this green refurbishment project led to a significant increase in the price of the property, making a noticeable profit at the point of sale.

\section{Policy implications}

A number of cities around the world have developed and implemented policies to encourage and require structures as green walls and roofs to appear in new development projects [12]. Reports collected and reviews of case studies done by the research group SBErnc [3] project have shown that the cities focused mostly on outcomes than processes of achieving biophilic projects, reporting rather on the size of allocated budget and structures. The report produced by SBErnc points to the most important issues, which have to be resolved to overcome challenges and barriers in achieving desirable biophilic outcomes. These are: reducing political and financial risk and leveraging opportunities; creating policies, guidelines and programs appropriate to any city's circumstances.

In this paper, the authors propose implementing a mechanism of land value capture as one way of funding biophilic projects by private investors.

To encourage and facilitate design based on biophilic urbanism strategies in urban regeneration projects, local governments should consider alternative ways of financing new investments. The proposed land value capture mechanism has been successfully used in the United States, Canada, Japan and Hong Kong [4]. It has been founded on a principle that land value is determined by its intrinsic value plus any private investment that is enabled because of investment in infrastructure, economic development and population growth [32].

The land value capture mechanism focuses mainly on attracting necessary funds to finance a new development project. It has been successfully used to finance new rail developments. The mechanism estimates the increased value on land around urban rail. The projected additional value is used to fund rail systems $[4,32]$. A similar approach could be used to fund biophilic urban projects: the land value capture mechanism could be used to calculate approximate land value increases and allocate the profits towards funding a biophilic urban infrastructure.

From the analysis of the selected case studies, it has clearly been shown that the increases in land values could be generated through a strategic design of the public amenities using the principles of biophilic urbanism. A local government can gain extra taxation revenues as a result of new development, without raising the existing rates [4]. These revenues can be forecast and included into future budgets as a means of paying for biophilic urban infrastructure costs up front.

It has been shown that urban greenery has the potential to uplift the value of land and adjacent properties. Therefore, it is likely that biophilic design principles informing strategic urban design may have the potential to further increase this value. Estimated financial gains increase by up to 50 percent as shown through the above analysis of selected case studies. The land value forecast could be used to 
attract capital to the project before it is built and by this way it can help to fund the project.

Extra land value could be added by introducing a biophilic design methodology to create healthy, environmentally responsible and regenerative green and blue infrastructure seamlessly woven into the built environment to enhance its economic value. Such a mechanism exists in Singapore where a green floor ratio is required to replace the floor plate of a building by 2 to 3 times the amount of greenery through green roofs, walls and balconies [29]. This innovation has become a major factor in the city's tourism and economic development.

A number of publications have shown that there is an emerging market in cities for biophilic urban regeneration, highlighting that homebuyers are choosing properties with close proximity to high quality urban open spaces. Furthermore, this increase in land value can be used to attract private and public investors to deliver new businesses in the area. New investments help to create vibrant neighbourhoods, indirectly lifting the value of all properties nearby.

This paper suggests that a government mechanism of land value capture can be used to create biophilic projects into the mainstream of urban policy.

\section{References}

[1] Beatley, T., Biophilic Cities: Integrating Nature into Urban Design and Planning, Island Press: Washington, 2010.

[2] Beatley, T. \& Newman, P., Biophilic Cities Are Sustainable, Resilient Cities, Sustainability, 5(8), pp. 3328-3345, 2013.

[3] Can biophilic urbanism deliver strong economic and social benefits? An economic and policy investigation into the increased use of natural elements in urban design; Sustainable Built Environment National Research Centre (SBEnrc), http://www.sbenrc.com.au/wpcontent/uploads/2013/11/sbenrc 1.5biophilicurbanism-industryreport.pdf

[4] Newman, P. \& Green, J., Paying for infrastructure means using 'land value capture', but does it also mean more tax? https://theconversation.com/ paying-for-infrastructure-means-using-land-value-capture-but-does-italso-mean-more-tax-58731

[5] Newman, P., Sustainable urbanisation: four stages of infrastructure planning and progress. Journal of Sustainable Urbanization, Planning and Progress, 1(1), pp. 3-10, 2016.

[6] Ecosystem Evaluation, http://www.ecosystemvaluation.org/hedonic pricing.htm

[7] Tomalty, R. \& Komorowski, B., The Monetary Value of the Soft Benefits of Green Roofs. Final report. Smart Cities Research Services: Montreal, 2010.

[8] Newman, P. \& Matan, A., Green Urbanism in Asia, World Scientific Publishing: Hackensack NJ, 2013.

[9] Kellert, S., Biophilic urbanism: the potential to transform. Smart and Sustainable Built Environment, 5(1), pp. 4-8, 2016. 
[10] Wilson, E. O., Kellert, S. R., The Biophilia Hypothesis, Island Press: Washington DC, 1993.

[11] Kellert, S., Heerwagen J. \& Mador, M.L., Biophilic Design. The Theory, Science, and Practice of Bringing Buildings to Life, John Wiley \& Sons: Hoboken NJ, 2008.

[12] Reeve, A., Desha, S., Hargroves, C., Newman, P. \& Hargreaves, D. (2013). A Basis for Inquiry into Policy Consideration for Increasing the Application of Biophilic Urbanism. In S. Rauch, G. Morrison, S. Norra, N. Schleicher (ed.), Urban Environment. Proc. of the 11th Urban Environment Symposium (UES), Karlsruhe, Germany, 16-19 September, Springer International Publishing: Dordrecht, Switzerland, pp. 143-151, 2012.

[13] 14 Patterns of Biophilic Design. Improving Health \& Well-being in the Built Environment; Terrapin Bright Green, 2012. http://www.terrapin brightgreen.com/reports/14-patterns/

[14] Newman, P. \& Jennings, I., Cities as Sustainable Ecosystems. Principles and Practices, Island Press: Washington DC, 2008.

[15] Clancy, J. \& Ryan, C., The Role of Biophilic Design in Landscape Architecture for Health and Well-being. Landscape Architecture Frontiers, 3(1), pp. 54-61, 2015.

[16] Crompton, J., The Impact of Parks on Property Values: Empirical Evidence from the Past Two Decades in the United States. Managing Leisure, 10(4), pp. 203-21, 2005.

[17] Wachter, S., The Determinants of Neighbourhood Transformations in Philadelphia - Identification and Analysis: The New Kensington Pilot Study, University of Pennsylvania, The Wharton School, 2004.

[18] Removing Freeways - Restoring Cities. Seoul, South Korea, Cheonggye Freeway; The Preservation Institute Web Site, Berkley CA, www.preservenet.com/freeways/FreewaysCheonggye.html

[19] Cheonggyecheon Stream Restoration Project - Seoul, South Korea Methodology for Landscape Performance Benefits; Landscape Architecture Foundation Web Site, Washington DC, http://landscapeperformance.org /case-study-briefs/cheonggyecheon-stream-restoration

[20] Green Infrastructure's contribution to economic growth: a review; Economics for the Environment Consultancy (eftec) and Centre for Regional Economic and Social Research (CRESR), Sheffield Hallam University Web Site, Sheffield, United Kingdom, http://www4.shu.ac.uk/ research/cresr/sites/shu.ac.uk/files/green-infrastructures-contributiongrowth.pdf

[21] Green Walls Benefits; Green Roofs for Healthy Cities Web Site, http://www.greenroofs.org/index.php/about/green-wall-benefits

[22] Peck S.W., Callaghan C., Kuhn M.E., Bass B. Greenbacks from Green Roofs: Forging a New Industry in Canada. Status Report on Benefits, Barriers and Opportunities for Green Roof and Vertical Garden Technology Diffusion; Peck \& Associates (P\&A), Toronto ON, 1999, https:/www.nps.gov/tps/sustainability/greendocs/peck-sm.pdf 
[23] Des Rosiers, F., Thériault, M., Kestens, Y., \& Villeneuve P., Landscaping and house values: An empirical investigation. Real Estate Research, 23, pp. 139-161, 2002.

[24] Ascher, K. \& Uffer, S., The High Line Effect. Proc. of the CTBUH Int. Conf. Conference On Global Interchanges: Resurgence of the Skyscraper. New York, 2015.

[25] Levere, M., The Highline Park and Timing of Capitalization of Public Goods; Department of Economics, UC San Diego Web Site, http://econweb.ucsd.edu/ mlevere/pdfs/highline_paper.pdf

[26] Triman, J., New urban rail parks seek to improve on High Line; Biophilic Cities Web Site, http://biophiliccities.org/new-urban-rail-parks-seek-toimprove-on-high-line/

[27] Foo, E., Award-winning 158 Cecil Street sold for \$240 million; New Launch 101 Web Site, https://newlaunch101.com/award-winning-158cecil-street-sold-for-240-million/

[28] Rashiwala, K., 158 Cecil Street being sold for S\$240m; Business Asia One Web Site, http://business.asiaone.com/news/158-cecil-street-being-solds240m\#sthash.05H1LcO2.dpuf

[29] Newman, P., Biophilic urbanism: a case study on Singapore. Australian Planner, 51(1), pp. 47-65, 2013.

[30] Lucchese, J., Green Wall Transforms Lifeless Building; Landscape Architects Network Web Site, http://landarchs.com/green-wall-transformslifeless-building/

[31] Case Study - 158 Cecil Street, Singapore; Alpha Investment Partner Limited Web Site, www.alphaipartners.com/EN-S-Case-Study-158-CecilStreet-Singapore.aspx

[32] Newman, P., Jones, E., Green, J. \& Davies-Slate, S., Entrepreneur Rail Model. A discussion paper; Curtin University, Perth, Australia, 2016. 